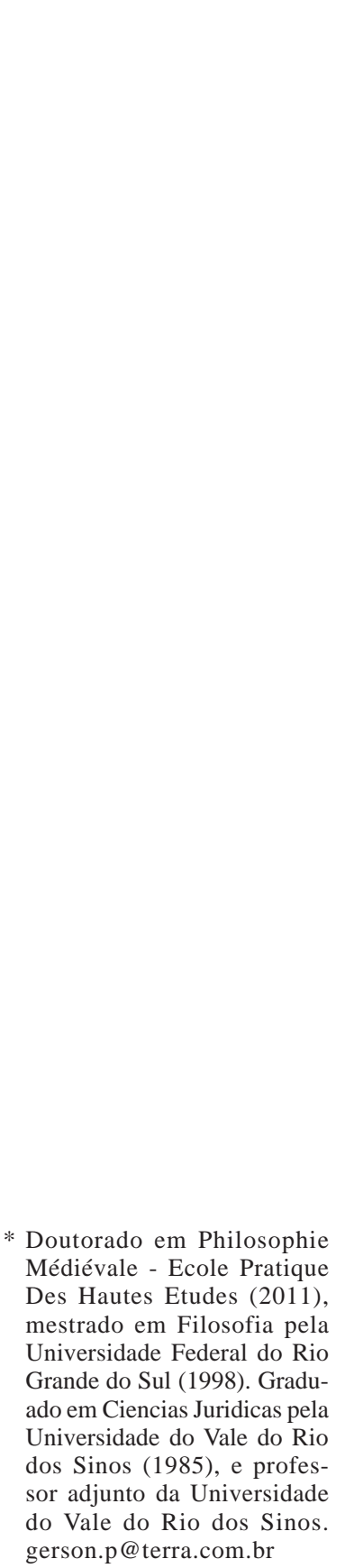

\title{
A invenção da bioética
}

THE INVENTION OF BIOETHICS

* Gerson Neves Pinto

Resumo: A Bioética está em permanente expansão no que se refere às novas questões morais e jurídicas, mas ainda é incipiente em sua fundamentação jurídico- filosófica. A noção de bioética apresenta-se como uma ética nova para um novo homem, onde as noções da ética clássica parecem não justificar as exigências das novas questões colocadas pela bioética. Este trabalho aborda a questão das novas tecnologias e de seus limites éticos e jurídicos. Para tanto, avalia-se as contribuições de dois dos mais importantes jus-filósofos contemporâneos sobre o tema, Jürgen Habermas e Ronald Dworkin, e um possível diálogo destes dois últimos com aquele que foi um dos fundadores da ética clássica, Aristóteles.

Palavras-chave: Ética; Bioética; Genética; Contingência e princípios.

Abstract: The Bioethics is in permanent expansion as regards the new moral and legal issues, but it is still incipient in his legal philosophical reasoning. The concept of bioethics presents itself as a new ethics for a new man, where the notions of classical ethics do not seem to justify the requirements of the new issues raised by bioethics. This work deals with the issue of new technologies and their ethical and legal limits. For both, it evaluates the contributions of two of the most important contemporary philosophers about the theme, Habermas and Dworkin, and a possible dialog of these last two with him that was one of the founders of classical ethics, Aristotle.

Keywords: Ethics; Bioethics; Genetics; Contingency and principles. 


\section{A INVENÇÃO DA BIOÉTICA}

No início do século XX Freud provocou a maior estupefação no meio médico de então, ao afirmar que a sexualidade infantil é algo constitutivo da neurose humana e que esta descoberta não deveria ser algo tão surpreendente e repulsiva, pois, na realidade, ele simplesmente estava recuperando aquilo que os gregos já sabiam há muito tempo e que está maravilhosamente narrado na tragédia de Sófocles, Édipo Rei: o destino inelutável do ser humano. Do mesmo modo, pode-se imaginar que, nos dias de hoje, com o advento da bioética, estejamos, novamente, diante de uma nova irrupção daquilo que os gregos já haviam prefigurado: a "caixa de pandora", aquilo que simboliza, uma vez aberta, a causa das maiores catástrofes, pois que nela se encontravam todos os males da humanidade. Para muitos a bioética se constitui numa "caixa de Pandora" às avessas, pois seria a redenção do ser humano no que diz respeito aos segredos da vida e, sobretudo, à possibilidade de transcender o humano, enquanto mortal, atingindo assim, o pós-humano ou o pós-natural.

Seja como for, a bioética é uma realidade e ela diz respeito a todos os setores da atividade humana: o início e o fim da vida, a engenharia genética, a biotecnologia moderna, a medicina e os medicamentos, etc. Enfim, a "caixa de Pandora" já foi aberta, para o bem ou para o mal. Isto é, a bioética está no nosso presente e estará, sem dúvida, no nosso futuro. O desafio agora é saber como devemos nos conduzir para uma adequada utilização destes descobrimentos e ter a consciência de que a bioética é que deverá tratar dos problemas atuais e futuros de ordem ambiental e éticos que, fundamentalmente, dizem respeito às liberdades individuais. É uma discussão, portanto, que transcende o plano meramente técnico e científico, dizendo respeito ao conjunto da sociedade que se vê frente à possibilidade de sofrer benefícios e malefícios.

O primeiro autor que, nos Estados Unidos, utilizou o vocábulo "bioética" foi Van Rensselaer Potterquien. Em 1970 ele usou a combinação Bio-Ethik, expressão que é composta das palavras gregas bios (vida) e ethos (ética) para designar o estudo da moralidade das condutas humanas no domínio das ciências da vida. Nesta nova abordagem acerca das condutas adotadas nas ciências biomédicas, temos sempre presente uma tensão entre o desenvolvimento técnocientífico e a questão ética dos limites que devem ser observados por estas novas tecnologias. Temos duas tendências aparentemente contraditórias envolvendo os avanços da bioética: estes desenvolvimentos técno-científicos ora emergem como melhorias das condições materiais da existência humana, 
ora aparecem como ameaças, colocando em perigo a vida humana, por avançarem por searas ainda não totalmente conhecidas.

Desde a criação do nome esta nova disciplina encerra uma ambigüidade fundamental: ela é ao mesmo tempo antiga e moderna, pois dizer "Ética" é evocar a genealogia do pensamento ocidental, onde é possível colocar "a nu as estruturas do Ocidente", como afirma o jurista Pierre Legendre (1985, pg. 13). Por outro lado, ela é mesmo pós-moderna naquilo que investiga, pois o seu objeto de saber são as novas tecnologias que por intermédio de pesquisas e experiências prometem trazer grandes benefícios ao gênero humano. A noção de bioética que aparece somente na década de 70 do Século XX nos EUA reenvia, primeiramente, a um conjunto de procedimentos e práticas que colocavam em dúvida os avanços das técnicas biomédicas. Esta postura cética e também crítica é sem dúvida uma característica da modernidade. A inovação propõe um novo ideal: uma ética nova, um mundo novo, um novo homem. Como se o espaço entre a vida e a morte, a saúde e a doença, a dor e a esperança, a anamnese e o tratamento dispensado ao homem pela ética médica não fosse mais o mesmo e nem fossem as mesmas noções da ética grega antiga as hoje utilizadas pela bioética. Enfim, como nos lembra Engelhardt (2003, pg. 438), "O súbito surgimento da bioética é um enigma: ela veio aparentemente do nada".

Para tentar entender este enigma, Habermas vai nos lembrar que todos os avanços nas técnicas e pesquisas constituem uma nova espécie de desafio, pois eles modificam aquilo que "somos por natureza" e, citando Kant, Habermas(2004, pg.38) vai afirmar:

Aquilo que Kant incluíra no "reino da necessidade" transformou-se com a visão teórico-evolucionista num "reino do acaso". A técnica genética está deslocando a fronteira entre essa base natural indisponível e o "reino de liberdade". ${ }^{1}$

Como afirmou o filósofo Habermas em seu livro Natureza Humana, as técnicas inovadoras provenientes da genética deslocaram a fronteira entre a base natural indisponível [aquilo que é necessário, eterno ou como o evolucionismo moderno denominou: o acaso] e o chamado reino da liberdade [domínio do contingente]. A intervenção das tecnologias naquilo que até então

\footnotetext{
${ }^{1}$ Este texto de Habermas $O$ Futuro da Natureza Humana. A caminho de uma eugenia liberal? Constitui-se numa versão redigida da conferência Christian Wolff, proferida na Universidade de Marburg em 28 de junho de 2001, que considerou a discussão sobre o tratamento que se deve dar às técnicas genéticas.
} 
era absolutamente natural ou por acaso (fecundação, gestação, mutações etc.) fez com que ocorresse uma ampliação do âmbito de intervenção do homem naquilo que era "natural", modificando assim, a estrutura geral de nossa experiência moral.

A esta modificação de nossa experiência moral, Habermas vai chamar de "destradicionalização dos mundos da vida". Neste ponto o posicionamento de Habermas coincide com o de Dworkin², pois o que Habermas (2004, pg.37) denomina "destradicionalização dos mundos da vida", Dworkin (2005, pg. 633) chama de "deslocamento moral"3. Podemos entender estas duas expressões como sinalizadoras de uma crise dos valores da tradição ético-moral ocidental para tratar e compreender as questões e problemas trazidos pelas rápidas mudanças na ciência, as quais hoje são objeto de reflexão da bioética, e suas aplicações nos diagnósticos, prognósticos e terapias médicas. Este novo horizonte, nos coloca frente a uma desafiante reformulação de problemas morais, jurídicos e políticos que o avanço destas novas tecnologias produzirá num futuro bem próximo.

Segundo Dworkin, em que pesem as diferentes convicções partilhadas por pessoas religiosas e por pessoas eruditas que utilizam a linguagem da ciência, algo em seus discursos é muito similar: tanto para os que entendem que Deus criou o mundo, quanto os que se baseiam na ciência acreditando na força cega da natureza, admitem a presença de uma linha divisória entre quem e o que somos. Ou seja, a divisão se estabelece entre o que a natureza criou, tanto do ponto de vista da criação divina [Deus] como de um processo evolutivo natural [acaso], e o que a humanidade decide fazer com tudo isto.

Temos assim, uma fundamental demarcação entre aquilo que nos é naturalmente dado e sobre o qual somos (ou éramos) completamente impotentes para interferir, e aquilo que, não estando naturalmente e inelutavelmente estabelecido, é objeto de deliberação entre fazer ou deixar de fazer, tal como sabemos desde os gregos.

Nesta linha basilar estabelecida entre o acaso (ou a sua versão teológica: Deus) e o que nós podemos realizar com o patrimônio pelo qual somos responsáveis, encontramos o que Dworkin (2005, pg. 632) considera a base de nossa ética e da nossa moralidade, afirmar: "Esse limite fundamental entre o

\footnotetext{
${ }^{2}$ Embora sustentem posições antagônicas, em certo sentido, Dworkin e Habermas também têm muitos pontos em comum, dos quais faremos referência somente dos principais.

${ }^{3}$ Michael Sandel em seu último livro Contra A Perfeição - Ética na Era da Engenharia Genética vai chamar esta revolução genômica de "vertigem moral".
} 
acaso e escolha é a espinha dorsal de nossa ética e da nossa moralidade, e qualquer alteração profunda nessa fronteira é um deslocamento grave.".

Destaca o autor que diante de temas tão intensos e frente a inovações científicas que acarretam mudanças modificam-se os valores de um extremo para outro. Deste modo, um período de estabilidade moral foi substituído pela insegurança moral, o que fez com que as pessoas recorressem ao termo "brincar de Deus", para designar o fato dos cientistas desvendarem e dominarem elementos da ciência que conferem poder sobre a natureza, ultrapassando o limite do que é(foi) considerado divino. O termo "brincar de Deus"4 também é utilizado por quem se opõem aos avanços da ciência, ao referir-se aos pacientes moribundos que passaram a tomar decisões e assumir responsabilidades por si a respeito de sua vida, atos que não aconteciam no passado, pois tal atitude ficava restrita aos desígnios de Deus (Dworkin, 2005, pg. 633). Neste contexto, surge o questionamento sobre como poderíamos entender e explicar o que ocorreu para que desta estabilidade moral nós passássemos a uma insegurança ou instabilidade moral.

Dworkin afirma que para tentar responder a estas questões devemos levar em conta as diversas conseqüências da biotecnologia moderna e a 'estrutura geral' de nossa experiência moral e ética, na medida em que a engenharia genética provocou uma profunda modificação no limite entre 'o que nos é dado naturalmente' e 'aquilo pelo que somos responsáveis'. A hipótese de Dworkin (2005,pg. 633) baseia-se no fato que a ciência genética, o progresso das ciências e das técnicas, que outorgam aos homens um poder cada vez maior sobre o curso [natural] das coisas, multiplicaram os problemas éticos, por intermédio de um deslocamento que altera o limite entre a sorte e a escolha que estrutura todos os nossos valores e, tal deslocamento ameaça "tornar obsoleta uma grande parte deles [de nossos valores morais]". Em função desta ameaça, nos encontramos apreensivos e inseguros quanto às nossas convicções morais arraigadas na tradição ética ocidental. A insegurança moral atual quanto às questões suscitadas pela biotecnologia moderna seria, para Dworkin, a sensação de que muitas de nossas convicções morais venham a ser solapadas e, desta forma, venhamos a sofrer 'uma espécie de queda-livre moral', onde tenhamos que pensar sobre novos dilemas morais tendo um novo pano de fundo e com resultados

${ }^{4}$ Como já havia afirmado Leibniz, comparando o homem com Deus: "Cada espírito sendo como uma pequena divindade" - "chaque Esprit étant comme une petite divinité dans son departement".

Leibniz(1981), pg. 148. 
incertos, bem como sobre novas questões éticas que nunca haviam sido pensadas pelo gênero humano.

A expressão "brincar de Deus” utilizada por Dworkin (2005, pg. 633), pode ser interpretada no sentido de que quanto mais nós somos ou pensamos ser "os mestres e possuidores da natureza", segundo a fórmula profética de Descartes $^{5}$ (e sabemos que Descartes esperava tudo da medicina do futuro), recorrendo a técnicas inovadoras e audaciosas, mais se exerce uma liberdade que nos aparece ilimitada. A ética, a moral e o direito, a partir deste novo quadro situacional de novas tecnologias, têm que formular novos limites e proteções jurídicas na regulação, produção e utilização destas inovações. A dimensão deste desafio fica delineada quando Dworkin afirma mais adiante no texto: Brincar de Deus é, de fato, brincar com fogo. Mas é isso que nós, os mortais, temos feito desde os tempos de Prometeu, o deus padroeiro da perigosa descoberta. Brincamos com fogo, pois a alternativa é a covardia perante o desconhecido. (2005, pg. 636).

Da mesma forma que Dworkin, Habermas (2004, pg.40) sustenta que estas inovações e modificações em técnicas genéticas são capazes de alterar as bases da experiência moral da sociedade. A técnica genética irá fazer frente às questões práticas, que dizem respeito a pressupostos de julgamentos e questões morais. Argumenta Habermas, que o deslocamento entre o acaso e a livre decisão mexe com a autocompreensão das pessoas, que são orientadas pela moral e estão preocupadas com a própria existência. Esse deslocamento conscientiza as pessoas das relações entre a autocompreensão moral e o interior da ética da espécie. Conforme o autor (Habermas,2004, pg.40), essa estrutura está sintonizada com a forma pela qual nós somos vistos como seres da mesma espécie e pelo modo de nós sermos responsáveis pela nossa trajetória de vida. Como nos explica Habermas, esta profunda modificação da estrutura geral de nossas

\footnotetext{
5 A medicina era um dos domínios do conhecimento que Descartes(1952, pg. 169) identificava como um dos mais promissores para o futuro da natureza humana: Car elles [ces connaissances] m'ont fait voir qu'il est possible de parvenir à des connoissances qui soient fort utiles à la vie; et qu'au lieu de cette philosophie spéculative qu'on enseigne dans les écoles, on en peut trouver une pratique, par laquelle, connoissant la force et les actions du feu, de l'eau, de l'air [...] et ainsi nous rendre comme maîtres et possesseurs de la nature. Ce qui n'est pas seulement à désirer pour l'invention d'une infinité d'artifices, [...] mais principalement aussi pour la conservation de la santé, laquelle est sans doute le premier bien et le fondement de tous les autres biens de cette vie; car même l'esprit dépend si fort du tempérament et de la disposition des organes du corps, que, s'il est possibles de trouver quelque moyen qui rende communément les hommes plus sages et plus habiles qu'ils n'ont été jusques ici, je crois que c'est dans la médecine qu'on doit le chercher.
} 
convicções normativas modernas se deve ao que ele chame de "ampliação da contingência": A distinção entre essa 'ampliação da contingência', relativa à natureza 'interna', e as ampliações semelhantes da nossa margem de opção está na circunstância de a primeira 'modificar a estrutura geral da nossa experiência moral”. (2004, pg.39).

\section{DESLOCAMENTO MORAL E AMPLIAÇÃO DA CONTINGÊNCIA}

Como poderíamos compreender este idéia que Dworkin denomina: "deslocamento moral" entre o acaso e a escolha ou como Habermas denomina a "ampliação da contingência" ?

Para tentar responder a esta questão sobre a diferença fundamental entre o grau de responsabilização do agente nas suas ações e aquilo que nos é dado como pano de fundo do nosso agir, Dworkin nos propõe a seguinte classificação: “a diferença fundamental está entre o que a natureza, incluindo-se nela a evolução, criou, por intermédio de partículas, energia e genes, e o que fazemos nesse mundo e com esses genes". (2005, pg. 632).

Poderíamos simplificar da seguinte maneira: Dworkin indica que temos de um lado os seres da natureza que, em si mesmos, têm um certo princípio e, de outro, o que sobre isso fazemos ou deliberamos, com uma tênue linha divisória. O que ele resumidamente abrevia como: "Esse limite fundamental entre o acaso e a escolha", isto é, o limite entre o que não se pode deliberar [o que é por natureza ou por acaso] e o que é passível de modificação e deliberação [escolha].

Na Ética Nicomaquéia de Aristóteles há uma enumeração muito similar a de Dworkin. À pergunta acerca de se podemos deliberar sobre tudo, Aristóteles $\left(1958,1112^{\mathrm{a}} 17-18\right)$ responde que as coisas a respeito das quais se pode escolher ou deliberar são bem restritas. Ele parte de uma prova negativa estabelecendo que ninguém delibera sobre o necessário. Afirma, ainda, que não deliberamos sobre aquilo que é impossível, pois, ninguém, pela mesma razão, pode escolher o impossível (como por exemplo, tornarse imortal). Nem deliberamos sobre as coisas da natureza (tais como as estações do ano) ou sobre aquilo que, embora não seja necessário, ocorre no mais das vezes, o mais freqüente, por exemplo, uma boa colheita. Por último, não deliberamos sobre aquelas coisas que acontecem por acaso. Enfim, dirá Aristóteles, somente deliberamos sobre aquilo que tanto pode 
vir a ser de um modo como de outro, isto é, aquilo que é contingente a respeito do futuro, cabendo ao homem determinar o que será por meio de sua escolha $\left(1958,1140^{a} 29-b 3\right)$.

Ao contrário de todas as demais hipóteses, apenas deliberamos acerca das coisas que podem ser realizadas pelos nossos próprios esforços e que dependem de nós para sua realização ou não. A deliberação ocorre então naquelas situações de ação onde nem sempre se obtém o mesmo resultado agindo da mesma maneira em razão das inúmeras variáveis, exigindo do agente atenção às circunstâncias concretas do caso com que se defronta. $\mathrm{O}$ exemplo referido por Aristóteles para ilustrar esta situação é o do médico (Aristóteles, 1958, 1112b1-10), pois ainda que os sintomas de seus pacientes sejam semelhantes, ele não pode indicar o mesmo tratamento para todos, já que se faz necessário ponderar acerca de todas as particularidades de cada organismo.

Neste ponto, estamos em condições de compreender qual o sentido da expressão "ampliação da contingência" ou "deslocamento moral" entre o acaso e a escolha. Como anteriormente referido, sobre as coisas que acontecem por acaso nós não deliberamos, só podemos deliberar sobre aquilo que está em nosso poder. Quando explicávamos a ocorrência de um evento qualquer como sendo por acaso [ou devido à própria natureza criada por Deus ou pelo evolucionismo] a ocorrência deste evento escapava ao nosso poder de decisão. A partir do momento em que avançamos nosso conhecimento acerca das causas do evento sobre o qual nós não decidíamos e, que hoje em dia, passamos a decidir, constatamos o aumento de nosso poder de decisão e escolha e, deste modo, aumentamos o espaço da contingência do agir humano. Avançamos o nosso conhecimento e conseguimos adequá-lo ao sentido das verdadeiras causas daquilo que, ou desconhecíamos (não sabíamos a verdadeira natureza do fenômeno), ou atribuíamos a existência do fenômeno a um encontro arbitrário de várias causas (seria unicamente fruto do acaso).

Esta argumentação pode ser ilustrada por intermédio da seguinte situação: a causa da cor dos olhos, antes do advento da genética, era atribuída ao acaso [ à natureza ou à providencia divina] e hoje, os geneticistas sabem muito bem qual é a causa, ou melhor dito, qual é o gene responsável pela cor dos olhos. Esta causa genética é [hoje] tão conhecida pelos geneticistas que é possível interferir e deliberar sobre a cor dos olhos. É perfeitamente exequiível [talvez não do ponto de vista ético], nos dias de hoje, que um casal escolha junto ao seu geneticista, qual seria a cor dos olhos do seu bebê, ou diversas outras 
características tais como altura, cor de pele e cabelo, bem como em relação a seus talentos ${ }^{6}$.

No início do século XX os cientistas não sabiam determinar quais eram os valores de verdade acerca das proposições sobre a cor dos olhos. Com as descobertas da engenharia genética passaram a dominar este saber e sobre ele deliberar. Ou seja, a biogenética está tornando disponível aquilo que era, até então, indisponível. É a esse tipo de situação que Habermas e Dworkin se referem ao afirmar que houve este "deslocamento moral" entre o acaso e a escolha e a concomitante "ampliação da contingência": aquilo que era considerado um evento meramente casual ou fortuito da natureza, revelou-se um evento que possui uma causa e, acima de tudo, causa esta a qual não só temos acesso, mas podemos sobre ela interferir, deliberar ou escolher. Dito de outro modo, o aumento da contingência acarreta uma ampliação do âmbito da deliberação e escolha moral. Ou seja, aquilo que antes era tido como "natural", hoje é perfeitamente passível de interferência humana, para o bem ou para o mal. No entanto, devemos fazer uma distinção crucial entre este tipo de deliberação que se verifica no agir humano e a deliberação técnica. Esta última encontra na técnica utilizada pelo médico, um bom exemplo. Mas qual é a diferença entre estes dois tipos de deliberação? Para podermos compreender esta distinção, vejamos em Aristóteles o que existe de similar entre estas duas deliberações e em que elas diferem.

\section{A DISTINÇÃO ARISTOTÉLICA ENTRE DELIBERAÇÃO TÉCNICA E A DELIBERAÇÃO ÉTICO-MORAL}

Quando na Ética Nicomaquéia Aristóteles descreve logicamente o tipo de raciocínio prático envolvido na deliberação, ele não está pensando somente na ética, mas também faz um paralelo com a técnica, especialmente a medicina

\footnotetext{
${ }^{6}$ Como nos afirma Habermas: "Os pais teriam a possibilidade e o direito de atuar antes do nascimento de seus filhos sobre algumas de suas características, disposições ou aptidões monogenéticas. Aqui prevejo a possibilidade de que o adolescente que venha a tomar conhecimento da manipulação prénatal de que foi objeto se sentirá limitado em sua liberdade ética. O adolescente poderá pedir explicações a seus pais, responsáveis pelo seu desenho genético. Ele poderá reprová-los pelo fato de o terem dotado de um talento matemático e não de aptidões atléticas ou musicais que o teriam tornado mais capaz para ser atleta ou pianista, que são as carreiras de seus sonhos. Ele poderá ainda reconhecer-se como único autor de sua biografia quando conhecer as intenções que guiaram os coautores na eleição de seu perfil genético? É certo que os pais desejam o melhor para seus filhos. Mas não podem saber qual dote será "o melhor" no contexto imprevisível de uma biografia que não é a sua" (Habermas, 2003).
} 
e a navegação, que funcionavam como paradigmas para explicar a ação humana. Em toda a teoria da deliberação sobre a tomada de decisão em casos e em situações de incerteza, Aristóteles utilizava-se dessa comparação, entre a deliberação moral [a deliberação propriamente prática] e a deliberação técnica. Ao introduzir a noção de deliberação nas primeiras frases da Ética Nicomaquéia [em 1112b1], ele o faz justamente mediante essa comparação entre a ação prática e a técnica, ou a arte. Para explicar em que consiste a deliberação, o exemplo que Aristóteles fornece é o exemplo do médico (Aristóteles, 1958, 1112b1-10).

Em outra passagem da Ética, Aristóteles (1959, 1087ª11-14) nos apresenta a seguinte situação: "Porque o médico nem sequer parece estudar a saúde desse ponto de vista [in abstracto], mas sim a saúde do homem, ou talvez seja mais exato dizer a saúde de um indivíduo particular, pois é aos indivíduos que ele cura."

O autor defende que a saúde é o conhecimento que está na alma do médico. Neste ponto, o estagirita propõe a seguinte indagação: qual o significado da afirmação de que o homem saudável seria o resultado da deliberação do médico. Ele estabelece a seguinte resposta na forma silogística: dado que $\mathrm{X}$ é saúde; para um paciente qualquer ser saudável, $\mathrm{X}$ deve estar presente. Aplicando este raciocínio onde o estado de equilíbrio do corpo representa a saúde, para que isto esteja presente, é preciso calor. O médico remonta assim progressivamente pelo pensamento até uma etapa final segundo a qual está em seu poder produzir calor. Seu desejo de curar o paciente é o ponto de partida de sua deliberação. Para que ele possa restabelecer a saúde do paciente é necessário produzir calor no corpo do paciente. Vamos supor que o médico saiba que há cobertores que estão ao seu alcance. Neste caso, diz Aristóteles $^{7}\left(1973,701^{\mathrm{a}} 17-22\right)$, o médico pensa: «tenho necessidade de [me] cobrir; ora um cobertor serve para cobrir; tenho necessidade de um cobertor». Conclusão: o médico toma imediatamente os cobertores para cobrir o paciente. A conclusão deste silogismo representa a ação a ser realizada: cobrir o

\footnotetext{
No tratado Movimento dos Animais, Aristóteles nos fornece mais informações sobre o processo de deliberação. A ação representa a conclusão de uma deliberação. No caso do homem, a imagem do silogismo chamado "prático" pode nos ajudar a compreender como seria uma deliberação. Tomemos o exemplo da passagem 701a17-22 do tratado Movimento dos Animais: «tenho necessidade de me cobrir ; ora um cobertor serve para cobrir; tenho necessidade de um cobertor. Isto do qual tenho necessidade, é necessário que eu o faça; tenho necessidade de um cobertor; é necessário pois fazer um cobertor». A conclusão deste silogismo representa a ação a ser realizada, o objeto desejado.
} 
paciente, aquecendo-o para restabelecer a saúde. Enfim, Aristóteles utilizase do exemplo do médico para nos ilustrar como se opera a deliberação. Os médicos da época de Hipócrates e de Aristóteles, bem como os médicos atuais, com o nível de conhecimento do Séc. XXI, deliberam usando os procedimentos deliberativos muito semelhantes ao que um agente moral ou um agente político utiliza. O que realmente Aristóteles quer dizer ao afirmar que os médicos deliberam? Por que os médicos simplesmente não utilizam procedimentos mecânicos para decidir o que fazer em relação a um paciente determinado? Por uma razão muito simples: porque não se possui um conhecimento, uma ciência, das diferentes doenças. O que temos é, de um lado, a técnica médica e, de outro, a ciência da biologia. Esta última, composta de enunciados universais que dizem que tais e tais fatores são causas de tal ou qual doença; tais e tais sintomas são indícios de tal ou qual doença. Mas, o que não existe é uma relação dedutiva, entre esses enunciados universais, que os médicos aprendem na faculdade de Medicina, e o caso singular do paciente. Aqueles sintomas que tal paciente apresenta são sintomas do quê? Isto é, o médico, nesta etapa, ainda não está interessado em saber qual é a relação causal entre aqueles sintomas do seu paciente e eventualmente tal ou qual procedimento médico, tais como quimioterapia, radioterapia etc. A primeira coisa que o médico tem de fazer é identificar aqueles sintomas como sendo isso ou aquilo, isto é, tal ou qual doença. A seguir, o médico passa à deliberação de natureza causal, isto é, identificar as causas da doença e buscar a sua possível cura. Temos também a deliberação do juiz, ao qual cabe aplicar a lei e avaliar todas as peculiaridades das circunstancias do caso concreto para decidir como dar-se-á a melhor adequação da lei ao caso. Deverá o juiz ponderar qual a melhor maneira de aplicar a lei, assim como o médico, enquanto médico, deverá avaliar como obter a cura do paciente.

Mas, apesar dessa similaridade, desse parentesco, há uma diferença lógica entre a deliberação técnica (técnica médica) e a deliberação da justiça política (na ação humana). No caso da deliberação judicial [do juiz] existe um aspecto ontológico intransponível da contingência do caso concreto e dos vários aspectos circunstanciais relevantes que podem ocorrer e que impedem que esta deliberação se limite apenas à análise universal e abstrata da lei. O juiz equânime delibera a partir das circunstâncias e consegue assim recolocar a lei em sua singularidade. Este juiz "não é outro senão o homem justo e prudente, aquele que toma as decisões em função e imerso na 
particularidade de cada ação" (Zingano, 2007, pg. 348.). Segundo Zingano (2007, p. 329), existe essa indeterminação no campo das ações que é antes ontológica do que epistêmica, ou seja, é uma indeterminação da própria ação como tal e não de um problema de maior ou menor conhecimento das variáveis envolvidas. É em função de uma obscuridade epistemológica que o médico desconhece a multiplicidade de variáveis envolvidas na aplicação daquele saber da biologia ao indivíduo X em concreto. Esta indeterminação da medicina como técnica é uma indeterminação epistêmica, ao nível do conhecimento ou falta deste. Quanto mais o médico conhece, menos delibera em sua técnica médica em relação ao paciente. Desta forma, o que diferencia esta deliberação [do médico, enquanto médico] da deliberação judicial [moral] é que nesta última, a indeterminação não é uma questão de conhecimento mas, como diz Aristóteles, é uma indeterminação com relação à matéria das ações humanas. Em outras palavras, é porque a matéria em que se dá o agir humano é ontologicamente variável, e isto inexoravelmente, que o agir ético será sempre contingente e jamais poderemos extingui-la, nem sequer diminuí-la com o incremento de nosso conhecimento. Aristóteles acredita que as ações sempre se dão no terreno ontologicamente indeterminado e esta indeterminação de base não depende de nosso conhecimento, mas diz respeito ao tipo de matéria que envolve as ações: a contingência ontológica.

$\mathrm{O}$ argumento do Estagirita é que, como a contingência no domínio técnico é essencialmente uma contingência epistêmica, ela, em princípio, poderá ser eliminada ou, pelo menos, diminuída. É claro que ela poderá ser reduzida, basta que nós desenvolvamos conhecimento suficiente para poder determinar o valor de verdade das proposições que compõem o saber da medicina. Em outras palavras, se o nosso conhecimento progride, nós podemos então construir teorias científicas capazes de nos permitir determinar qual é o valor de verdade das proposições que nos interessam dentro da medicina e que antes eram atribuídas unicamente ao acaso e, assim, deixavam uma margem de deliberação para o médico ${ }^{8}$. Isto está cada vez mais sendo colmatado pela ciência, pela biologia. Com isso,

\footnotetext{
${ }^{8}$ Podemos tomar como exemplo a invenção do raio X pelo físico alemão Wilhelm Röntgen (18451923). Röntgen é considerado o pai da Radiologia de Diagnóstico - a especialidade médica que utiliza imagem para o diagnóstico de doenças- a qual permitiu aos médicos realizarem diagnósticos mais rápidos e precisos. Podemos verificar neste exemplo que temos aqui um acréscimo do conhecimento da medicina, mas ao mesmo tempo, uma diminuição no grau de deliberação do médico.
} 
conseguimos compreender o aparente paradoxo: quanto maior o conhecimento da medicina, menor o grau de deliberação do médico9 .

Como podemos compreender por que a medicina, enquanto uma técnica, possui uma deliberação precária e que depende do caráter desconhecido de determinadas doenças? Do mesmo modo, como vimos anteriormente, na medida em que esta obscuridade desaparece, diminui também a deliberação do médico. Na Ética Nicomaquéia, com efeito, Aristóteles exclui a deliberação das "ciências" (112b1-5), mas inclui técnicas como a navegação e a medicina, cujos resultados não são sempre os mesmos e dependem de nós a sua realização. Em outra de suas obras, denominada Etica Eudemia, porém, Aristóteles questiona porque os médicos deliberam sobre aquilo que eles têm ciência, mas não os gramáticos (Aristóteles, 1997, 1226a35). A razão oferecida é que há um duplo erro na medicina (no raciocínio e na percepção ao aplicar os resultados da deliberação), enquanto, na gramática, há um único tipo de erro (o da percepção). $\mathrm{O}$ ponto aqui é que no caso da medicina, o erro podendo ser, de um lado, a determinação das causas de uma determinada doença e, de outro, a aplicação destes resultados a um paciente em concreto, a medicina sempre envolveria alguma indeterminação de como proceder. Sempre resta algo obscuro e indefinido diz Aristóteles ao afirmar que "a deliberação diz respeito àquelas coisas que, produzindo-se num bom número de casos, permanecem incertos em sua realização, e nas quais é indeterminado" (1112b8-10).

É neste âmbito, onde se conjuga o universal da ciência (os princípios da biologia) e o particular (este paciente), que o saber do médico dificilmente eliminará totalmente esta indefinição. Sempre restará algo para deliberar nesta aplicação ao caso concreto. É aí que a bioética se mostra fundamental, pois é nesta relação com o paciente que o médico deverá expressar a sua deliberação que é técnica, mas que deverá ser harmonizada com a deliberação moral do paciente ou de seu representante. A bioética, portanto, é que deverá tratar destes novos problemas éticos, os quais têm como origem estas novas tecnologias.

\footnotetext{
${ }_{9}$ Isto não significa que Aristóteles esteja afirmando, como fez Descartes(cf. nota 11) que isso fatalmente ocorrerá. O que Aristóteles está dizendo é que se a contingência no domínio técnico é essencialmente epistêmica, então, em princípio, do ponto de vista puramente lógico, não há nenhum obstáculo na possibilidade da eliminação da contingência epistêmica. Ao contrário, a contingência ontológica, dado que a contingência não depende de nós, não depende do nosso conhecimento, ela é, portanto, ineliminável. Esse saber é, portanto, um saber de natureza deliberativa e jamais pode se transformar num mero saber de natureza teórica. Essa é a razão pela qual, para Aristóteles, não pode haver uma ciência da moralidade, uma vez que para ele existe uma indeterminação dos assuntos práticos e que esta não é uma indeterminação de ordem epistêmica, mas de ordem ontológica. Ou seja, a indeterminação não é eliminada pelo mero acréscimo de conhecimento que venhamos acumular.
} 


\section{CONSIDERAÇÕES FINAIS}

O que resulta claro e que se impõe como conclusão é que as decisões neste campo transcendem o plano meramente técnico. É uma discussão que diz respeito aos principais atores desta cena: desde o médico, com a sua deliberação técnica, até o paciente, com a sua deliberação moral.

Neste contexto, podemos compreender esta afirmativa com a idéia de uma "ampliação da contingência" por meio do advento das técnicas modernas. $\mathrm{O}$ que pode diminuir é a contingência da técnica médica que, enquanto técnica, depende de uma questão epistemológica do conhecimento. Quanto mais o médico tem o seu conhecimento como uma ciência e utilizar procedimentos mecânicos para decidir o que fazer em relação a um paciente determinado, menos liberdade ele terá como médico. O mesmo não se verifica no caso do agente moral ou do juiz, pois as circunstâncias das ações impõem ao agente moral sempre uma variabilidade, assim como no caso do juiz, onde a lei permite uma ampla variação de interpretações e onde é impossível uma transmissão mecânica entre a lei universal e o caso particular. Ao contrário do médico, no caso do agente moral, o que aumenta é a deliberação moral [ou judicial] da ação, pois como vimos esse tipo de indeterminação dos assuntos práticos não é uma indeterminação de ordem epistêmica, ou seja, sua indeterminação não é minimizada pelo progresso ou acúmulo de conhecimento, mas o que se amplia é o campo de aplicação de nosso agir diante de problemas que antes eram tidos como inevitáveis, naturais ou por acaso e que agora caberá ao agente moral (o paciente ou em alguns casos, o próprio juiz) deliberar moralmente sobre o caso e ao agente técnico (o médico que vai concretizar a ação) em sua deliberação técnica.

Esta contingência agora não é mais uma deliberação meramente técnica, mas é principalmente uma deliberação moral: $\mathrm{O}$ agente ao deliberar quando vai desligar um aparelho que suporta um paciente terminal; decidir o sexo e a cor dos olhos do bebê, decidir se vai ou não destruir um embrião para remover células-tronco para utilização em novos experiências envolvendo novos tratamentos etc. são todas deliberações morais que ampliaram a liberdade e o agir humano e que devem ser tratadas como questões não meramente de ordem técnica, mas ao contrário, devem ser corretamente compreendidas como deliberações morais-judiciais e como 
tais devem ser enfrentadas. Por isso, neste tipo de deliberação, quem deve proferir a decisão não pode ser aquele que delibera de forma técnica meramente ${ }^{10}$ (como o médico, por exemplo), mas deve ser uma deliberação política-jurídica envolvida na ação por intermédio do paciente, da família do paciente ou, em última instância, do juiz ${ }^{11}$.

Neste ponto, podemos reler as afirmações de Dworkin e Habermas acerca do deslocamento moral e aumento da contingência sob o olhar de Aristóteles: o que Aristóteles nos lembra o tempo todo é que as decisões acerca dos problemas da ética ou da bioética não dizem diretamente respeito aos avanços da técnica da medicina como tal. Ou seja, por mais que a medicina evolua e que os médicos tenham um amplo saber sobre o corpo humano e suas propriedades essenciais, as questões acerca das decisões e escolhas a serem feitas pelos agentes morais (enquanto pacientes ou juízes) dizem respeito à deliberação política jurídica. Abre-se assim um novo campo de questões morais e jurídicas que antes não se colocavam pelo simples fato de que não existiam as condições fáticas para a sua formulação. ${ }^{12}$ Temos assim, neste recuo da linha demarcatória entre o que era "natural" e que agora passamos a intervir, um espaço lacunoso que poderíamos denominar de berçário de questões que alimentarão os problemas éticos jurídicos do século XXI.

\footnotetext{
${ }^{10}$ Nas questões do exercício da profissão de médico, os conselhos de medicina têm um papel fundamental na fixação das diretrizes da bioética. Mas ao estabelecerem estes marcos éticos do profissional da medicina, os médicos o fazem não enquanto médicos, mas enquanto cidadãos.

${ }^{11}$ Isto é, há uma diferença irrecuperável entre a deliberação técnica e a deliberação moral: a deliberação técnica é, do ponto de vista lógico, em princípio, eliminável. Quem delibera é o médico em sua deliberação técnica, mas em principio não há nenhuma barreira lógica que impeça a transformação, portanto, a eliminação ou a substituição da deliberação do médico por um outro modo de técnica. Existem hoje programas de diagnóstico médico por computador. Nestes tipos de operações, que ainda estão hoje em fase experimental, o conhecimento médico está se tornando não mais um conhecimento prático, porque não tem mais nenhuma deliberação; está se tornando um conhecimento científico, isto é, o conhecimento epistêmico, uma ciência teórica no sentido aristotélico. O que parece ser um limite intransponível desta deliberação é o fato de que os resultados da medicina aplicar-se-ão a um paciente em concreto. E, cada vez que nos aproximamos do particular, mais exceções surgem: a morfologia do paciente, a sua vida desregrada ou não, os seus hábitos e vícios, sua alimentação, sua herança genética, etc.

${ }^{12}$ Algo similar poderia ser pensado com a questão do meio ambiente. Aristóteles escreveu inúmeros tratados sobre a relação do homem com os demais animais. No entanto, ele não vai se perguntar sobre a extinção de animais ou sobre a poluição do meio-ambiente. Aristóteles valorizava fortemente o estudo dos animais por relação aos seres divinos, como nos lembra Labarrière (2005, pg. 228), ao afirmar que ele, citando Heráclito, dizia: "Entrez, il y a des dieux aussi dans la cuisine". Deste modo, Aristóteles nos convida a ver de perto como se estuda a natureza e como ela funciona. Mas é claro que neste estudo não aparece o problema da destruição e aniquilação dos meios de subsistência do planeta e a sua completa poluição. Estes problemas relativos ao meio ambiente somente surgirão com a revolução industrial.
} 


\section{REFERÊNCIAS}

ARISTOTE. Étique à Nicomaque. Introduction, traduction et commentaire de René Antoine GAUTHIER e Jean Yves JOLIF, Publications Universitaires de Louvain - Éditions Béatrice-Nauwelaerts, Paris, 989p. 1959.

1997.

. Éthique à Eudème, traduction de Vianney Décarie, Vrin, Mouvement des Animaux, texte établi et traduit par P. Louis, Paris, Les Belles Lettres, Paris, 1973.

BORRILLO, Daniel, La république des experts dans la construction des Lois : le cas de la bioéthique, Revue Histoire@ Politique 2/ 2011 (n¹4), p. 55-83.

BRAUNSTEIN, Jean-François. Bioéthique ou philosophie de la médecine ? Revue de métaphysique et de morale, 2014/2 ( $\left.\mathrm{N}^{\circ} 82\right)$, p. 239 - 256, Presses Universitaires de France, Paris.

DESCARTES, René. Discours de la méthode, $6^{\text {ème }}$ partie, CEuvres et Lettres, Gallimard, Paris, 1952.

DWORKIN, Ronald. A virtude soberana: a teoria e a prática da igualdade. São Paulo: Martins Fontes, 2005.

ENGELHARDT, H. Tristam Jr. Pluralismo moral e metafísico. Repensar a santidade da vida e da dignidade humanas. In GARRAFA, Volnei \& PESSINI, Leo (Org.). Bioética: poder e injustiça. São Paulo: Loyola, 2003.

HABERMAS, Jürgen. O Futuro da natureza humana: a caminho de uma eugenia liberal? Trad. Karina Jannini. São Paulo: Martins Fontes, 2004.

HABERMAS, J. Por una ética de Ia especie humana. Clarín, Buenos 
Aires, Argentina, entrevista, 8 fev. 2003.

HIRSCH, Emmanuel (ed) Traité de Bioéthique. Fondements, principes, repères. Éditions Ères, Paris, 2010.

LABARRIÈRE, Jean-Louis. La condition animale: études sur Aristote et les Stoïciens, Louvain-La-Neuve, Éditions Peeters, Leuven, 2005.

LEGENDRE, P. L'inestimable objet de la transgression, étude sur le principe généalogique en Occident, Paris, Fayard, 1985.

LEIBNIZ, Monadología, Edición trilingüe. Introducción de Gustavo Bueno Traducción de Julián Velarde, Pentalfa Ediciones, Oviedo 1981.

PUYBASSET, Louis. Enjeux ethiques en Réanimation. Editeur : Springer Verlag France, 2010.

SANDEL, Michael. Contra a perfeição - ética na era da engenharia genética. Civilização Brasileira, Rio de Janeiro, 2013.

ZINGANO, Marco. Estudos de ética antiga. São Paulo: Discurso Editorial, 2007.

Submetido em: 12/10/2013 Aprovado em: 21/10/2014

Como citar: PINTO, Geson Neves. A invenção da bioética. Scientia Iuris, Londrina, v.18, n.2, p.211-226, dez.2014. DOI: 10.5433/2178-8189.2014 v18n2p211. 